\title{
Methanolic extract of Moringa oleifera leaves induces Cell cycle arrest and downregulates Mitochondrial membrane potential in Dalton's Lymphoma cells.
}

\section{Sandeep Kumar}

Banaras Hindu University

\section{Alok Shukla}

Banaras Hindu University https://orcid.org/0000-0003-1942-0104

\section{Praveen Kumar Verma}

Banaras Hindu University

Rishi kant Singh

Banaras Hindu University

\section{Naveen Kumar}

Banaras Hindu University

\section{Anand kumar Patel}

Banaras Hindu University

\section{Lokesh Yadav}

Banaras Hindu University

\section{Sanjay Kumar}

Banaras Hindu University

Arbind Acharya ( $\nabla$ acharya@bhu.ac.in )

Banaras Hindu University

\section{Research Article}

Keywords: Moringa oleifera, Dalton's Lymphoma, antiapoptotic, mitochondrial membrane potential

Posted Date: October 4th, 2021

DOI: https://doi.org/10.21203/rs.3.rs-953524/v1

License: () (1) This work is licensed under a Creative Commons Attribution 4.0 International License. Read Full License 
Methanolic extract of Moringa oleifera leaves induces Cell cycle arrest and down-regulate mitochondrial membrane potential in Dalton's Lymphoma cells

\begin{abstract}
Cancer is a group of diseases characterised by abnormal and undifferentiated cell growth that has the potential to spread to other parts of the body. It is the world's second leading cause of death and morbidity. According to the GLOBOCAN 2020 report, out of 19.3 million new cancer cases and 10 million deaths reported, 544352 new cases and 259793 deaths occurred by non-Hodgkin lymphoma (NHLs). Although, numerous therapeutic approaches like, surgery, radiotherapy, chemotherapy and immunotherapy have been developed to treat cancer, limited success has been achieved, possibly due to severe side effects associated with the drugs used during chemotherapy. Therefore, deciphering the novel compound with least side effects and highly potent against cancer is urgently required. In the present study we used leaf extract of M. oleifera, well-known for its anti-cancer efficacy against different cancer cells, however, its effect on Dalton's lymphoma, a type of spontaneously occurring $\mathrm{T}$ cell lymphoma originated in the thymus of DBA mice is seriously lacking. Therefore, present study was aimed to analyze the therapeutic efficacy of $M$. oleifera against DL cells. Our results show that leaf extract of M. oleifera (MOML) significantly induces morphological changes in DL cells followed by chromatin condensation, nuclear fragmentation, and ROS generation. We also found significant changes in mitochondrial membrane potential $(\Delta \Psi \mathrm{m})$ in a dose dependent manner. Furthermore, apoptosis of DL cells induced by cell cycle arrest at G2/M and S phase suggested that MOML could be used to treat NHL effectively.
\end{abstract}




\section{Introduction}

Cancer is a group of disease occur in multi-cellular organism, characterized by an uncontrolled proliferation and irregular growth of abnormal cells. It is the second leading cause of mortality and morbidity worldwide [1,2]. According to the GLOBOCAN 2020 report, about 19.3 million new cancer cases and 10 million deaths were reported in 2020 . Report further suggested that out of the 19.3 million new cancer cases 10 million deaths in 2020, 83087 new cases and 23376 deaths by Hodgkin Lymhoma and 544352 new cases and 259793 deaths by non-Hodgkin lymphoma (NHLs) occurred worldwide. Non-Hodgkin's lymphoma is a group of heterogeneous malignant cells of the lymphatic system, characterized by an uncontrolled growth and proliferation of T cells, B cells or both [3]. Dalton's lymphoma (DL) is one of the most common NHL reported in the mice. DL is a spontaneously occurring transplantable T-cell lymphoma arises in the thymus of murine mice, and mimics human T cell lymphoma [4]. Although, numerous therapeutic approaches like, surgery, radiotherapy, chemotherapy and immunotherapy have been developed, limited success achieved in the treatment of cancers. The drugs used during chemotherapy, a most frequently and widely used approach to cure cancer, causes mild to severe side effects in the patients. Therefore, deciphering the novel compound with least side effects and highly potent against cancer is urgently required.

Moringa oleifera is the most prevalent cultivated angiospermic deciduous perennial tree of the family Moringaceae. It is widely distributed in the tropics and subtropics of Asia including India, Philippines, Cambodia, Central America, North and South America, Saudi Arabia and the Caribbean Islands [5]. The plant has numerous common names across regions where it is cultivated, like drumstick tree, horse radish tree, kelor tree or 
simply moringa in English [6]. It has high nutritional and medicinal values, and therefore, frequently used in India both as nutritional and medicinal purposes [7]. The medicinal properties of moringa lies in their different parts like, leaves, bark, seed and root help in the treatment of cardiovascular diseases, diabetes, and rheumatoid arthritis [8]. The methanolic extract of the leaves contains several potent bioactive compounds such as flavonoid pigments (kaempferol, rhamnetin, isoquercitrin and kaempferitrin), polyphenols, phenolic acids, minerals, and vitamins [9] that shows antimicrobial, antioxidant, antihypertensive, anti-inflammatory, and anticancer properties [10,11]. Furthermore, M. oleifera leaves are rich source of glycoside compounds, isothiocynates, beta-sitosterol, glucosinolates, gitoxigenin and betulic acid that shows significant anti-cancer properties [12, 13, 14]. Various reports suggested the anti-cancer efficacy of $M$. oleifera against different cancer cells [15], however, there is no any study suggesting the anti cancer activity of leaf extract of M. oleifera in Daltons lymphoma. Therefore, present study was aimed to analysis the therapeutic efficacy of $M$. oleifera against DL cells. Our results showed that leaf extract of M. oleifera significantly induces apoptosis and arrest cell cycle progression at G1 phase in DL cells.

\section{Materials and methods}

\subsection{Plant material and preparation of methanolic leaf extract}

Greenish fresh leaves of $M$. oleifera were collected from Botanical garden, BHU, Varanasi (Uttar Pradesh), India. The collected leaves were washed gently 2-3 times with autoclaved double distilled water, and carefully air dried. Leaves were grinded into a fine powder; added $10 \mathrm{gm}$ leaves powder in $100 \mathrm{ml}$ methanol in a $200 \mathrm{ml}$ round bottom flask and mixed for 10-12 $\mathrm{hr}$ until all components were dissolved. Filtered the extract with the help of Whatman filter paper and 
evaporated in a rotatory vacuum evaporator at $50^{\circ} \mathrm{C}$. The filtrate obtained was stored at $-20^{\circ} \mathrm{C}$ for further experiment.

\subsection{Maintenances of Animal}

The 8-10 week old inbred population of pathogen-free adult BALB/c $\left(H^{2} d\right)$ mice of either sex were used in the study. Mice were kept in a conventional polystyrene cage with an utmost pathogen free condition; sterilized food and water ad libitum were given to the mice.

\subsection{Reagents}

Cell culture media RPMI-1640 and foetal bovine serum (FBS) obtained from Gibco by life technologies $^{\mathrm{TM}}$. Penicillin, Streptomycin and L-glutamine were procured from HiMedia, Mumbai, India. Tissue culture flat bottom plates (6 wells and 96 wells plates) procured from Eppendorf India Private Limited, Chennai. Dimethyl sulphoxide (DMSO), 3-(4,5dimethylthiazol-2-yl)-2,5 diphenyltetrazolium bromide (MTT) were purchased from HiMedia, India. Acridine orange (AO) obtained from Sisco Research Laboratory (SRL). Ethidium bromide (EtBr) was procured from LobaChemie. Propidium Iodide (PI) was obtained from calbiochem. DAPI, DCF-DA, Rh-123 were purchased from Sigma Chemical Co. (St. Louis, MO, USA). Annexin V-FITC apoptosis detection kit was obtained from Invitrogen, USA. All other chemicals of high purity grade used were purchased from local Firm.

\section{GC-HRMS analysis of methanolic leaf extract of $M$. oleifera}

Analysis of phytochemicals present in the methanolic extract of Moringa leaves was done by gas chromatography combined to mass spectrometer (GC-HRMS) (AccuTOF GCV) at SAIF 
laboratory, IIT Bombay, Powai, Mumbai, India. [16]. This technique is the combination of gas chromatography and mass spectrometry used to find out different biologically active phytochemicals present in the methanolic leaf extracts of M. oleifera (MOML).

\section{MTT assay}

The cytotoxicity of methanolic leaf extract of M. oleifera (MOML) was determined by MTT assay [17]. Briefly, added $1 \times 20^{4} \mathrm{DL}$ cell/ well in a 96 well flat bottom ELISA plate and treated with different concentration $(100,200,250,300,350,450 \mu \mathrm{g} / \mathrm{ml})$ of methanolic extract of $M$. oleifera for $24 \mathrm{hr}$ in a humidified chamber with $5 \% \mathrm{CO}_{2}$ at $37^{\circ} \mathrm{C}$. After incubation $15 \mu \mathrm{l}$ MTT ( $5 \mathrm{mg} / \mathrm{ml}$ ) added into each well and incubated further for $4 \mathrm{~h}$. Aspirate the media carefully and added $100 \mu \mathrm{DMSO}$ each well to dissolve formazan crystals. The absorbance was taken at $595 \mathrm{~nm}$ with the help of ELISA plate reader (Bio-Rad, CA, USA). The percent viability of the DL cells was determined with respect to control by using the equation given below:

$\%$ Cell Viability $=[$ Absorbance in the treated group $] /$ [Absorbance in the untreated group $] \times$ 100.

\section{Reactive oxygen species (ROS) estimation}

The secretion of intracellular oxidative ROS by cells after treatment was analyzes with the help of DCFH-DA staining [18]. Briefly, $1 \times 10^{5}$ DL cells per well in a 6 wells culture plate were treated with different concentration of MOML and incubated in a $\mathrm{CO}_{2}$ incubator at $37^{\circ} \mathrm{C}$ temperature for $24 \mathrm{~h}$. Subsequently, washed the cells twice with chilled PBS and stained with $20 \mu \mathrm{M}$ DCFH-DA dye for $25 \mathrm{~min}$ in dark. Thereafter, cells were washed again with PBS and re-suspend in $100 \mu \mathrm{R}$ RMI-1640 media. Intensity of green fluorescence was observed under fluorescence microscopy (EVOS FL Microscopy by Life technologies) at 
X20 magnification. The intensity of DCF fluorescence was also analyzed with the help of flow cytometer at FL1-H channel (Becton Dickinson, California, USA).

\section{Ao/Etbr staining}

Acridine orange/ethidium bromide is a fluorescence dye used to observe the changes occurred in the nucleus of apoptotic cells [19]. To identify the morphological changes in DL cells after MOML treatment, $\mathrm{AO} / \mathrm{EtBr}$ staining was performed. Briefly, $1 \times 10^{5} \mathrm{DL}$ cells were treated with the different concentration $(150,300$ and $450 \mu \mathrm{g} / \mathrm{ml})$ of MOML. After treatment cells were stained with $\mathrm{AO} / \mathrm{EtBr}(10 \mu \mathrm{g} / \mathrm{ml})$ in $1: 1$ ratio and incubated for $15 \mathrm{~min}$ at $37^{\circ} \mathrm{C}$ in dark condition. Finally, the image was captured by fluorescence microscope (EVOS FL Microscopy by Life technologies).

\section{DAPI Staining}

DAPI (4',6-diamidino-2-phenylindole) is a blue fluorescence dye particularly binds with A-T rich consensus sequences of DNA molecules in the minor groove [20] used to study morphological changes in the nuclei of DL cells. Briefly, $1 \times 10^{5}$ DL cells were treated with different concentration of MOML and incubated for $24 \mathrm{hr}$ in $\mathrm{CO}_{2}$ incubator at $37^{\circ} \mathrm{C}$. After incubation cells were washed twice with chilled PBS followed by centrifugation. Stained the cells with DAPI $(5 \mu \mathrm{g} / \mathrm{ml})$ for 15 min in dark and observed under fluorescence microscopy (EVOS FL Microscopy by Life technologies).

\section{Cell Cycle analysis}

The effect of MOML on cell cycle was analyzed with the help of flow cytometer. Briefly, 5 $\times 10^{5}$ DL cells treated with different concentration of MOML in a 6 well culture plate and incubated in a $\mathrm{CO}_{2}$ incubator at $37^{\circ} \mathrm{C}$ for $24 \mathrm{~h}$. Washed the cells twice with chilled PBS, 
fixed in chilled $70 \%$ ethanol by gentle agitation and kept overnight at $4^{\circ} \mathrm{C}$. Decanted ethanol, rinsed cells twice with chilled PBS and stained with a cocktail containing $25 \mu \mathrm{g} / \mathrm{ml}$ of PI and $15 \mu \mathrm{g} / \mathrm{ml}$ of RNAase solution for $20 \mathrm{~min}$ in dark at room temperature. The treated cells were assessed using flow cytometry at FL2-A channel (Becton Dickinson, California, USA).

\section{Mitochondrial membrane potential (MMP)}

A change in the mitochondrial membrane potential is an important factor leads to apoptosis of the cell. Mitochondrial membrane potential $(\Delta \Psi \mathrm{m})$ are typically assessed using Rhodamine-123, cationic fluorescence dyes [21]. Briefly, $1 \times 10^{5}$ DL cells per well treated with different concentration of MOML and incubated in a humidified chamber with $5 \% \mathrm{CO}_{2}$ at $37^{\circ} \mathrm{C}$ for $24 \mathrm{~h}$. Washed the cells twice with PBS and stained with Rhodamine-123 dye for 30 min in dark at room temperature and observed under fluorescence microscopy at X40 magnification (EVOS FL Microscopy by Life technologies). Further, fluorescence intensity of treated cells was measured by flow cytometry at FL1-H channel (Becton Dickinson, California, USA).

\section{Quantification of Apoptosis with Annexin V and PI staining}

Effect of MOML on the apoptosis of DL cells was measured with the help of Annexin V and PI staining. In brief, $2 \times 10^{5} \mathrm{DL}$ cells seeded in a 6 well culture plate were treated with different concentrations of MOML and incubated in a $\mathrm{CO}_{2}$ incubator at $37^{\circ} \mathrm{C}$ for $24 \mathrm{~h}$. Washed the cells twice with chilled PBS, and centrifuged at $1500 \mathrm{rpm}$ for $5 \mathrm{~min}$. Resuspended the pellets in $200 \mu \mathrm{l}$ Annexin binding buffer containing $2 \mu 1$ fluorochromeconjugated Annexin- $\mathrm{V}$ and incubated in dark for $15 \mathrm{~min}$ at room temperature. After 
incubation cells were added with $2 \mu$ l Propidium Iodide staining solution and incubated further for $20 \mathrm{~min}$ at $37^{\circ} \mathrm{C}$. Analyzed the cells using flow cytometer, and data obtained were further analyzed by Flow Jo software (USA).

\section{DNA Fragmentation Assay}

Apoptosis is a natural phenomenon of cell death recognised by cytoplasmic condensation, membrane blebbing, and nuclear pycnosis followed by nuclear DNA fragmentation [22]. The fragmented DNA was assessed by agarose gel electrophoresis. DL cells $\left(2 \times 10^{5}\right)$ were treated with 300 and $450 \mu \mathrm{g} / \mathrm{ml}$ concentrations of MOML for $24 \mathrm{~h}$ and incubate in a $\mathrm{CO}_{2}$ incubator at $37^{\circ} \mathrm{C}$. Washed the cells with PBS, added DNA lysis buffer $(40 \mathrm{~m} \mathrm{MNaCl}$, 20mM Tris $\mathrm{HCl} \mathrm{pH} 8.0,5 \mathrm{mM}$ EDTA and 1\% SDS), and kept for 20-30 min on ice. Added Proteinase-K $(20 \mathrm{mg} / \mathrm{ml})$ and Rnase-A $(10 \mathrm{mg} / \mathrm{ml})$ to the cells and incubated for $2 \mathrm{~h}$ at $37^{\circ} \mathrm{C}$. Precipitate DNA using $5 \mathrm{M} \mathrm{NaCl}$ and absolute ethanol and stored at $-20^{\circ} \mathrm{C}$ overnight. Washed the pellet with $70 \%$ ethanol and air dried. Dissolved pellet in sterile distilled water and electrophoresed on to agarose gel containing $0.5 \mu \mathrm{g} / \mathrm{ml}$ ethidium bromide for better visualization of the DNA. Bands were visualized and analyzed with the help of gel documentation system (E-Gel ${ }^{\mathrm{TM}}$ Imager system by Themofisher).

\section{Results}

\section{GC-MS analysis of MOML}

The chromatogram of GC-MS analysis showing the peaks of different compounds present in the methanolic extract of $M$. oleifera (Fig. 1). Analysis of the peaks further show that $M$. 
oleifera plant contains 14 major bioactive compounds namely, Betulin, Gitoxigenin, 3Bromopropyl phenyl ether, Lupeol, Cedran-diol, 8S-14, Olean-12-ene-3,28-diol, [3ß], Lanosta-8,24-dien-3-ol, 1-monolinoleoylglycerol trymethylsilyl ether, $\quad \beta$ amyrintrimethylsilyl ether, 2-formyl-4-methylpentanoic acid, cyclopentaneundecanoic acid, 2-propyl-tetrahydropyran-3-ol, 2-octanone, 1-nitro, Isosorbidedintrate with different molecular weight, retention time, chemical formula, peak area and peak width as described in the table 1.

\section{M. oleifera leaf extract reduced cell viability}

Cell viability and cytotoxic effects of MOML was evaluated by standard MTT assay. Results show that MOML reduced viability of DL cells in concentration dependent manner as compare to control, and $\mathrm{IC}_{50}$ value was found to be $300 \mu \mathrm{g} / \mathrm{ml}$ (Fig. 2). In further experiments, $150,300,450 \mu \mathrm{g} / \mathrm{ml}$ doses of MOML were used for cell treatment.

\section{MOML induces intracellular ROS generation in DL cells}

Generation of Reactive Oxygen species (ROS) play an important roles in apoptosis induction [23]. The effect of MOML on ROS generation in DL cells was assessed by fluorescence microscope and flow cytometer. Results show that generation of ROS in treated cells increases in a concentration dependent manner with respect to the control. Further, secretion of ROS was examine by flow cytometer and found that groups of treated cells exhibit significantly increased ROS level, 46.44\%, 56.11\% and $60.57 \%$ respectively in concentration dependent manner suggested $450 \mu \mathrm{g} / \mathrm{ml}$ as a most effective dose as compared to $6.44 \%$ in control (Fig.). 


\section{MOML alter nuclear morphology of DL cells}

Analysis of cells after DAPI staining under fluorescence microscopy shows that MOML induce apoptosis in DL cells in a dose dependent manner. Treatment with different concentration of MOML for $24 \mathrm{~h}$ induce significant morphological changes in the nucleus of DL cells, as result, fragmented nuclei with condensed chromatins were observed. Results further show that when the cells were treated with $300 \mu \mathrm{g} / \mathrm{ml}$ MOML numbers of fragmented nuclei with condensed chromatins was significantly higher as compared to other concentrations. However, morphological changes induce by MOML in the nucleus of DL cells at any concentration was always higher than control or untreated cells (Fig. 3).

\section{MOML induces apoptosis in DL cells}

Apoptosis is an energy-dependent biochemical mechanism of programmed cell death that play critical role in maintaining cellular homeostasis in tissues [24]. Flow cytometry analysis of cells after $\mathrm{AO} / \mathrm{EtBr}$ staining shows that cells treated with different doses of MOML display high proportion of yellowish green fluorescence with damaged cell membrane indicating early stage of apoptosis. However, the remaining cells show orange/red fluorescence with condensed nucleus that indicates late stage of apoptosis. Apoptosis induced by MOML was further confirmed by Annexin V/PI staining, and found that percentage of apoptotic cells increases by $13 \%, 16 \%$ and $70.9 \%$ respectively as compared to control group in dose dependent manner (Fig. 9a and 9d). These observations suggested that MOML treatment effectively induce apoptosis in DL cells to maintain cellular homeostasis. 
MOML arrest G2/M and S phase of cell cycle of DL cells

After measuring apoptotic potential of MOML, an experiment was performed to study its effect on cell cycle. After treatment with different concentrations of MOML for $24 \mathrm{~h}$ cells were stained with Propidium Iodide (PI) and the cell cycle progression was assessed by FACs. Results show that treatment with different doses of MOML effectively arrested $26.96 \%, 36.24 \%$ and $36.75 \%$ cells at $\mathrm{G} 2$ phase, whereas $8.08 \%, 10.5 \%$ and $12.46 \%$ cells were arrested at $\mathrm{S}$ phase respectively (Fig. $\underline{8 \mathrm{a}}$ and $\underline{8 \mathrm{~b}}$ ). It is evident from the result that higher dose of MOML $(450 \mu \mathrm{g} / \mathrm{ml})$ is more effective in arresting cells at G2 and S phase. Although, difference between the percentage of cells arrested at $\mathrm{S}$ phase by $300 \mu \mathrm{g} / \mathrm{ml}$ and $450 \mu \mathrm{g} / \mathrm{ml}$ MOML was not significant, it was always higher when compared with control. Based on these observations, we concluded that MOML has ability to inhibit cell cycle progression at different stages, and down regulate DL progression.

\section{MOML down-regulated mitochondrial membrane potential $(\triangle \Psi m)$ in DL cells}

Any changes in the normal function of mitochondria causes depolarization of mitochondrial membrane potential, as a result apoptosis occur [25]. Therefore, to measure the effect of MOML, pre-treated cells were stained with Rhodamine-123, a lipophilic cationic fluorescence dye accumulated inside mitochondria of living cells and emit fluorescence analyzed with the help of flow cytometer. Our results show that different doses of MOML treatment significantly reduced mitochondrial membrane potential $(66.9 \%, 75.2 \%$, and 83.2\% respectively) in DL cell as compared to untreated cells (56.8\%). Further analysis of results revealed that $450 \mu \mathrm{g} / \mathrm{ml}$ MOML was most effective in down regulating MMP as compared to control. Since, lower membrane potential is directly related with the induction of apoptosis, one can assumed that MOML is effective in inducing apoptosis in DL cells. 
MOML induce DNA Fragmentation of DL cells

To validate the apoptotic effect of MOML on DL cells, DNA fragmentation assay was performed. During apoptosis intracellular endonucleases are activated and cleave the internucleosomal linker DNA, as a result genomic DNA fragmentation occur [26]. The DNA fragmentation assay show bands of different size of DNA on the gel that confirm DNA fragmentation induced by MOML treatment. The result obtained further suggested that 300 and $450 \mu \mathrm{g} / \mathrm{ml}$ dose of MOML were more effective in inducing apoptosis after $24 \mathrm{~h}$ as compared to lower dose. However, at any dose, MOML induces apoptosis in more cells as compared to the control.

\section{Discussion}

It has been reported that more than $60 \%$ medicinal plants exhibits cytotoxic properties and effective directly or indirectly against different types of cancer [27]. The GC-MS analysis shows that 14 major biologically active compound are present in MOML, where some of them having well reported anticancer properties [28]. Over past decades, M. oleifera leaves or its extract have been using effectively as antibacterial, anti-inflammatory, antioxidant, anti-parasitic, and anticancer agent $[29,30,31]$. Several studies have shown that M. oleifera exert significant anti-cancer activity against MCF-7, MDA-MB 231, EAC, HCT-8, Kasumi1, A549 cancer cells by interfering with signalling cascade that promote development and proliferation of cancer cells [32]. However, the antitumor and anti-proliferative efficacy of MOML against NHLs, preferably T cell lymphoma have not explored yet.

Reactive oxygen species (ROS) is an effective stress mediated cellular intermediate metabolite acts as a secondary messenger in cell signalling, and play crucial role in various biochemical process with pro-survival activity in healthy cells [33]. However, due to high metabolic and peroxisome activities, cancer cells produces large amount of reactive oxygen species (ROS) that kill cells [34, 35]. Keeping this fact in view, we performed a 
comprehensive study using DCFH-DA staining to find out the effect of MOML on ROS generation. We found that MOML treatment effectively induces ROS generation in DL cells. Results also suggested that secretion of ROS is dose dependent and therefore, highest cytotoxity was observed at highest dose of MOML. However, at any dose secretion of ROS was always higher when compared to the control or untreated cells.

First time we reported putative effect of MOML on the growth and proliferation of $\mathrm{T}$ cell lymphoma in vitro and found remarkable anti-proliferative activities against DL cells. We also found that MOML was effectively reducing cell viability of DL cells in concentration dependent manner, where highest cell death occurs at $400 \mathrm{mg} / \mathrm{ml}$ MOML. Although, it was earlier reported that leaves extract of M. oleifera cell decreases viability in several cancer [36], their effect on apoptosis was not deciphered in T cell lymphoma. Therefore, we further analyzed the effect of MOML on DL cells apoptosis and found that MOML effectively induces membrane blebbing, chromatin condensation, nuclear fragmentation and formation of apoptotic bodies at higher dose, which are directly correlated with apoptosis. Results from DAPI, AO/EtBr staining analysis suggested that MOML not only down regulate DL cell proliferation, but also induces apoptosis to maintain normal cellular homeostasis of the tissue in dose dependent manner [37, 38]. Further Annexin V/PI staining and Flow cytometer analysis of MOML treated DL cells show that most of the cells undergo apoptosis due to their cell cycle arrest at early and late phase, suggest significant anti-proliferative potential of MOML. However, these effects were dose dependent and maximum effects observed when the cells were treated with highest dose.

We next perform an experiment to study the effect of MOML on mitochondrial membrane potential. Studies have reported that mitochondria is a highly polarised organelle play important roles in several biochemical processes like oxidative phosphorylation, electron transport chain, and apoptosis [39]; however, any change in mitochondrial membrane 
potential results in the signals transduction that triggers apoptosis [40]. This fact prompts us to study MOML effect on mitochondrial membrane potential. We perform an experiment where DL cells treated with different concentration of MOML for $24 \mathrm{~h}$ stained with Rhodamine 123, a cationic lipophilic fluorescence dye and measure mitochondrial membrane potential using flow cytometer. Results show that MOML effectively down regulate mitochondrial membrane potential of DL cells in concentration dependent manner, which triggered signalling cascade leads to apoptosis. Further, to validate the apoptotic effect of MOML on DL cells, DNA fragmentation assay was performed. Results show bands of different size of DNA on the gel that confirm DNA fragmentation thereby, apoptosis of DL cells after MOML treatment. Our results also suggested that MOML at higher dose is more effective in inducing ROS generation, cell cycle arrest, depolarization of mitochondrial membrane resulting in apoptosis, and confirm anticancer properties of methanolic extract of M. oleifera leaves.

\section{Conclusion}

The results obtained from in vitro study clearly show potent cytotoxic efficacy of methanolic extract of Moringa oleifera leaves on DL cells. MOML decreases viability of DL cells, and increased apoptosis by inducing membrane blebbing, and nuclear and chromatin condensation. It also induces ROS generation, increases number of early and late apoptotic cells, and disrupting mitochondrial membrane potential in DL cells in concentration dependent manner. We also found that MOML significantly increase DNA fragmentation in DL cells in dose dependent manner. On the basis of these observations, we concluded that MOML is highly cytotoxic against DL cells and modulate expression of several key factors and pathways responsible for inducing apoptosis, and thus can be used as an anticancer 
agent. However, further investigation at molecular level is required before considering for preclinical application.

\section{Author contributions}

SK was involved in conception and design and perform the experiments. PKV and AS analysed all the experimental data. RKS contributed to drafting the article. AKP, LY and NK prepared reagents and helped during experiments. SK contributed to revising it critically for important intellectual content. AA made the final approval of the version to be published.

\section{Acknowledgments}

Sandeep Kumar highly thankful to the Council of Scientific and Industrial Research (CSIR), New Delhi, India for the award of Junior Research Fellowship [File No: 09/013(0791)/2018EMR-I]. We are also thankful to the DST- SERB (P-07/705) and Banaras Hindu University for providing financial support to carry out the proposed work. The instrumental facilities provided by Interdisciplinary School of Life Sciences (ISLS), Banaras Hindu University is highly acknowledged. 


\section{References}

1. Bray F, Jemal A, Grey N, Ferlay J, Forman D. Global cancer transitions according to the Human Development Index(2008-2030): a population-based study. Lancet Oncol. 2012;13(8):790-801.

2. Sharma H, Parihar L, Parihar P: Review on cancer and anticancerous properties of some medicinal plants. J Med Plant Res 2011;5:1818-1835.

3. Armitage, J.O., Gascoyne, R.D., Lunning, M.A., Cavalli, F., 2017. Non-hodgkin lymphoma. Lancet 390, 298-310, 10091.

4. Khynriam D, Prasad SB. Cisplatin-induced genotoxic effects and endogenous glutathione levels in mice bearing ascites Dalton's lymphoma. Mutat Res 2003;526:9-18.

5. Matic I, Guidi A, Kenzo M, Mattei M, Galgani A. Investigation of medicinal plants traditionally used as dietary supplements: Areview on Moringa oleifera. J Public Health Afr. 2018; 9(3):841.

6. Anwar, F.; Latif, S.; Ashraf, M.; Gilani, A.H. Moringa oleifera: A food plant with multiple medicinal uses.Phytother. Res. 2007, 21, 17-25.

7. L. Gopala krishnan, K. Doriya, D.S.Kumar, Moringa Oleifera: A Review on Nutritive Importance and its Medicinal Application, Food Science and Human Wellness (2016).

8. Fahey JW: Moringa oleifera: a review of the medical evidence for its nutritional, therapeutic, and prophylactic properties. Part 1. Trees Life J 2005:1-5.

9. Berkovich L, Earon G, Ron I, Rimmon A, Vexler A, et al.: Moringa oleifera aqueous leaf extract down-regulates nuclear factor-kappa $\mathrm{B}$ and increases cytotoxic effect of chemotherapy in pancreatic cancer cells. BMC Complement Altern Med 13, 1-7, 2013.

10. Tiloke C, Phulukdaree A, and Chuturgoon AA: The antiproliferative effect of Moringa oleifera crude aqueous leaf extract on human esophageal cancer cells. J Med Food 19, 398-403, 2016.

11. El-Bakry K, Toson E, Serag M, and Aboser M: Hepatoprotective effect of Moringa oleifera leaves extract against carbon tetrachloride - induced liver damage in rats. World J Pharm Sci 5, 76-89, 2016.

12. Guevara, A.P., Vargas, C., Sakurai, H., Fujiwara, Y., Hashimoto, K., Maoka, T., et al., 1999. An Antitumor promoter from Moringa oleifera Lam. Mut. Res. 440, 181188. 
13. Fuglie, L.J., 1999. The Miracle Tree: Moringaoleifera: natural nutrition for the Tropics, Church World Service, Dakar, p.68; Revised in 2001 and published as The Miracle Tree: The Multiple Attributes of Moringa, p. 172.

14. Anwar, F., Latif, S., Ashraf, M., Gilani, A.H., 2007. Moringa oleifera: a food plant with multiple uses. Phytother. Res. 21, 17-25.

15. Abdul rahman Khazim Al-Asmari, Sulaiman Mansour Albalawi, Md Tanwir Athar, Abdul Quaiyoom Khan, Hamoud Al-Shahrani, and Mozaffarul Islam. Moringa oleifera as an Anti-Cancer Agent against Breast and Colorectal Cancer Cell Lines. PLoS One. 2015; 10(8): e0135814.

16. Merlin NJ, Parthasarathy V, Manavalan R, Kumaravel S, Chemical Investigation of Aerial Parts of Gmelina asiatica Linn by GC-MS, Pharmacognosy Res., 1(3), 2009, 152-156.

17. Chowrasia D, Karthikeyan C, Choure L, Sahabjada, Gupta M, Arshad M. Synthesis, characterization and anticancer activity of some fluorinated 3,6-diaryl-[1,2,4] triazolo[3,4-b][1,3,4]thiadiazoles. Arabian J Chem.2013 (in press).

18. J.R. Heo, G.A. Lee, G.S. Kim, K.A. Hwang, K.C. Choi, Phytochemical-induced reactive oxygen species and endoplasmic reticulum stress-mediated apoptosis and differentiation in malignant melanoma cells, Phytomedicine. 39 (2018) 100-110.

19. S. Kasibhatla, G. P. Amarante-Mendes,D. Finucane, T. Brunner,E. Bossy-Wetzel, and D. R. Green,"Acridine orange/ethidiumbromide (AO/EB)staining to detect apoptosis," CSH Protocols, vol. 2006, no. 3, 2006.

20. H. Lee, H. Cho, R. Yu, K. Lee, H. Chun, and J. Park,"Mechanisms underlying apoptosis-inducing effects of kaempferol in HT-29 human colon cancer cells,"

21. Lemasters JJ, Qian T, He L, Kim JS, Elmore SP, Cascio WE, Brenner DA. Role of mitochondrial inner membrane permeabilization in necrotic cell death, apoptosis, and autophagy. Antioxid Redox Signal. 2002;4:769-781.

22. Cohen G.M., Sun X., Snowden R.T., Dinsdale D., Skilleter D.N.., Biochemical J., 1992, vol. 286 (pg. 331-334).

23. Saikolappan S., Kumar B., Shishodia G., Koul S., Koul H.K. Reactive oxygen species and cancer: A complex interaction. Cancer Lett. 2019;452:132-143. doi: 10.1016/j.canlet.2019.03.020.

24. Pfeffer, C.M., Singh, A.T., 2018. Apoptosis: a target for anticancer therapy. Int. J. Mol. Sci. 19 (2), 448. 
25. Ly JD, Grubb DR, Lawen A. The mitochondrial membrane potential (deltapsi(m)) in apoptosis; an update. Apoptosis. 2003;8:115-128.

26. D. Wlodkowic, W. Telford, J. Skommer, Z. Darzynkiewicz, Apoptosis and beyond: cytometry in studies of programmed cell death, Methods Cell Biol.103 (2011) 55-98.

27. Cragg GM, Newman DJ (2005). Plant as source of anticancer agents. $J$ Ethnopharmacol, 100, 72-9.

28. Awodele O, Oreagbaa IA, Odomaa S, Teixeira da Silva JA, Osunkaluc VO (2012). Toxicological evaluation of the aqueous leaf extract of Moringa oleifera Lam. (Moringaceae). J Ethnopharmacol, 139, 330-6.

29. Anwar F, Latif S, Ashraf M, Gilani AH (2007). Moringa oleifera: a food plant with multiple-medicinal uses. Phytother Res, 21, 17-25.

30. Gasparotto JrA, Gasparotto FM, Lourenco ELB, et al (2011). Anti-hypertensive effects of isoquercitin and extracts from Tropaeolummajus L: evidence for the inhibition of angiotensin converting enzyme. J Ethnopharmcol, 134, 363-72.

31. Ferreira RS, Napoleao TH, Santos AF, et al (2011). Coagulant and antibacterial activities of the water-soluble seed lectin from Moringa oleifera. Lett Appl Microbiol, 53, 186-92.

32. Tiloke C, Phulukdaree A, Chuturgoon AA. The antiproliferative effect of Moringa oleifera crude aqueous leaf extract on cancerous human alveolar epithelial cells. BMC complementary and alternative medicine. 2013;13(1):226.

33. Manda G, Nechifor MT, Neagu T (2009) Reactive oxygen species, cancer and anticancer therapies. Curr Chem Biol 3:342-366.

34. Cadenas, E. (2004). Mitochondrial free radical production and cell signaling. Molecularaspects of medicine, 25(1), 17-26.

35. Simon, H. U., Haj-Yehia, A., \& Levi-Schaffer, F. (2000). Role of reactive oxygen species (ROS) in apoptosis induction. Apoptosis, 5(5), 415-418.

36. Tiloke C, Phulukdaree A, Chuturgoon AA. The antiproliferative effect of Moringa oleifera crude aqueous leaf extract on cancerous human alveolar epithelial cells. BMC complementary and alternative medicine. 2013;13(1):226.

37. M. Blank and Y. Shiloh, "Programs for cell death: apoptosis is only one way to go," Cell Cycle, vol. 6, no. 6, pp. 686-695, 2007.

38. S. Baumann, A. Krueger, S. Kirchhoff, and P. Krammer,"Regulation of T cell apoptosis during the immune response,"Current Molecular Medicine, vol. 2, no. 3, pp. 257-272, 2002. 
39. Green DR, Reed JC. Mitochondria and apoptosis. Science 1998; 281: 1309-1312.

40. Gottlieb, S. M. Armour,M. H. Harris, and C. B. Thompson, "Mitochondrial membrane potential regulates matrix configuration and cytochrome c release during apoptosis," Cell Death and Differentiation, vol. 10, no. 6, pp. 709-717, 2003. 
Figures

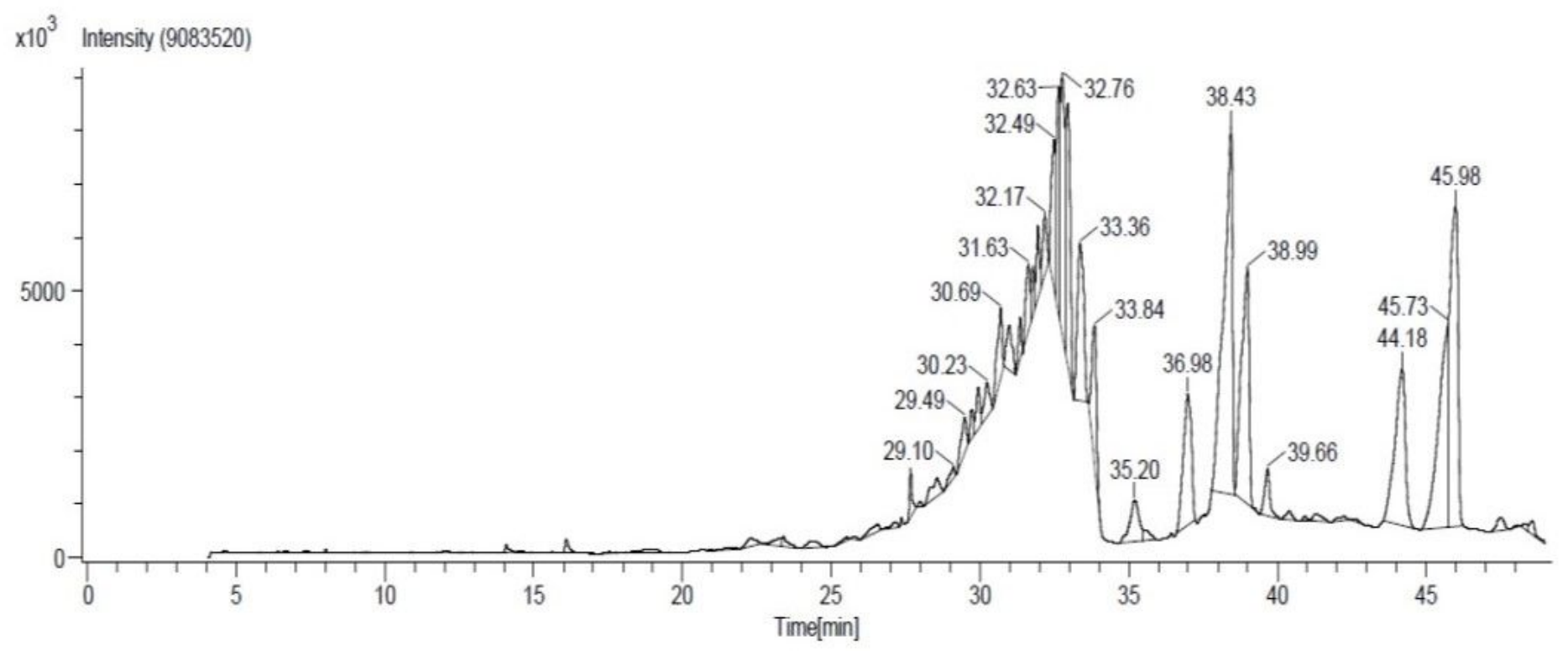

Figure 1

The chromatogram was obtained from the GC-HRMS with the methanolic extract of Moringa oleifera leaves.

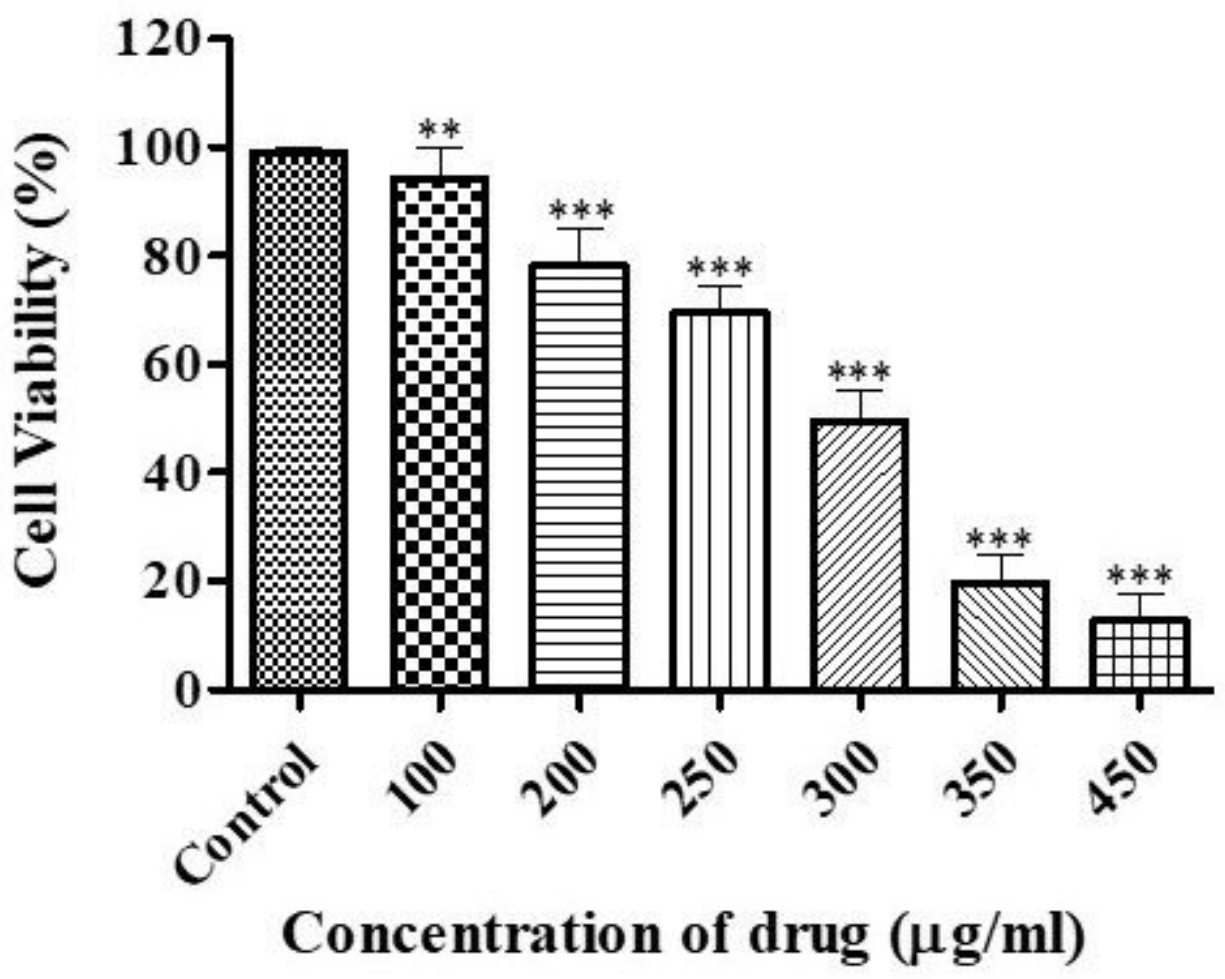

Figure 2 
DL cells were incubated with indicated concentrations of MOML for 24hrs and cytotoxic activity of MOML was measured by standard MTT assay. The results were denoted as a percentage of control $\pm S D$ and statistically analyzed via using Bonferroni posttests as well as unpaired T-test (two-way ANOVA) for at least three independent experiments.

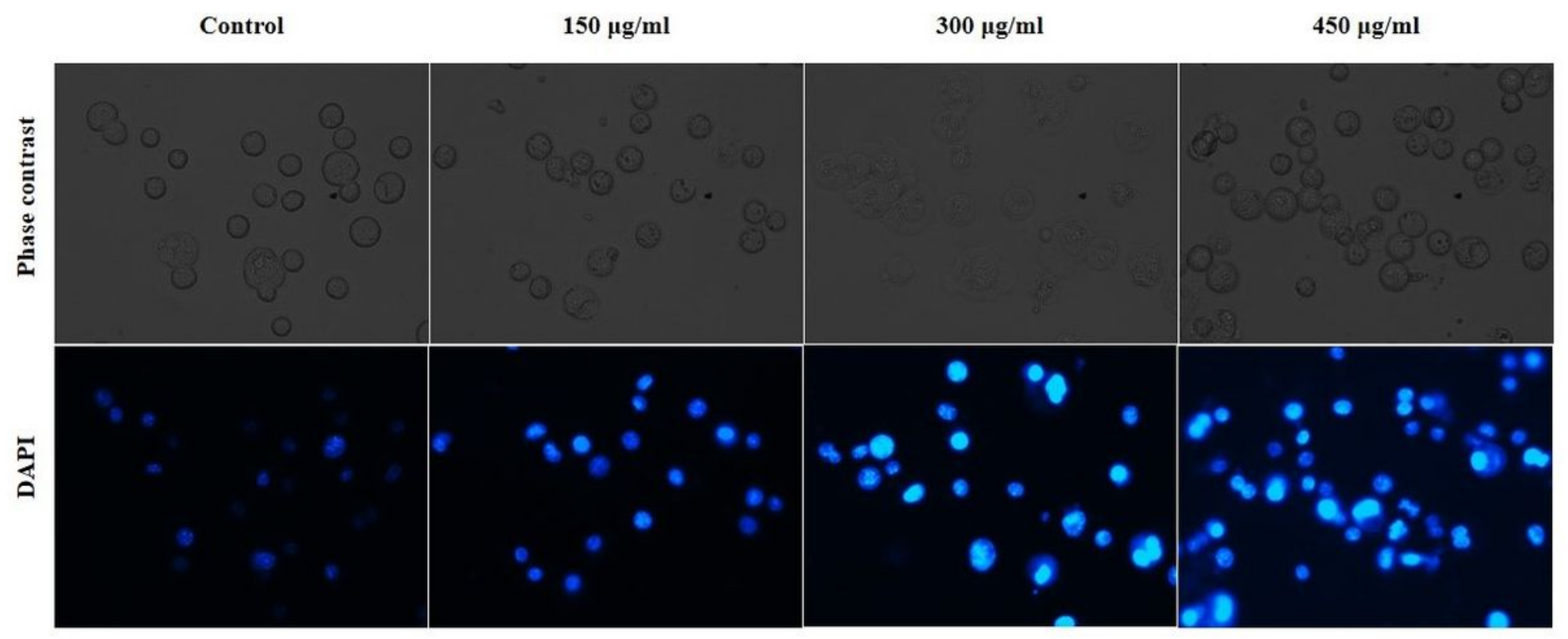

\section{Figure 3}

MOML treated and control cells were stained with the nuclear stain DAPI. Observation of Nuclear morphology was done by fluorescent microscope(40x). 


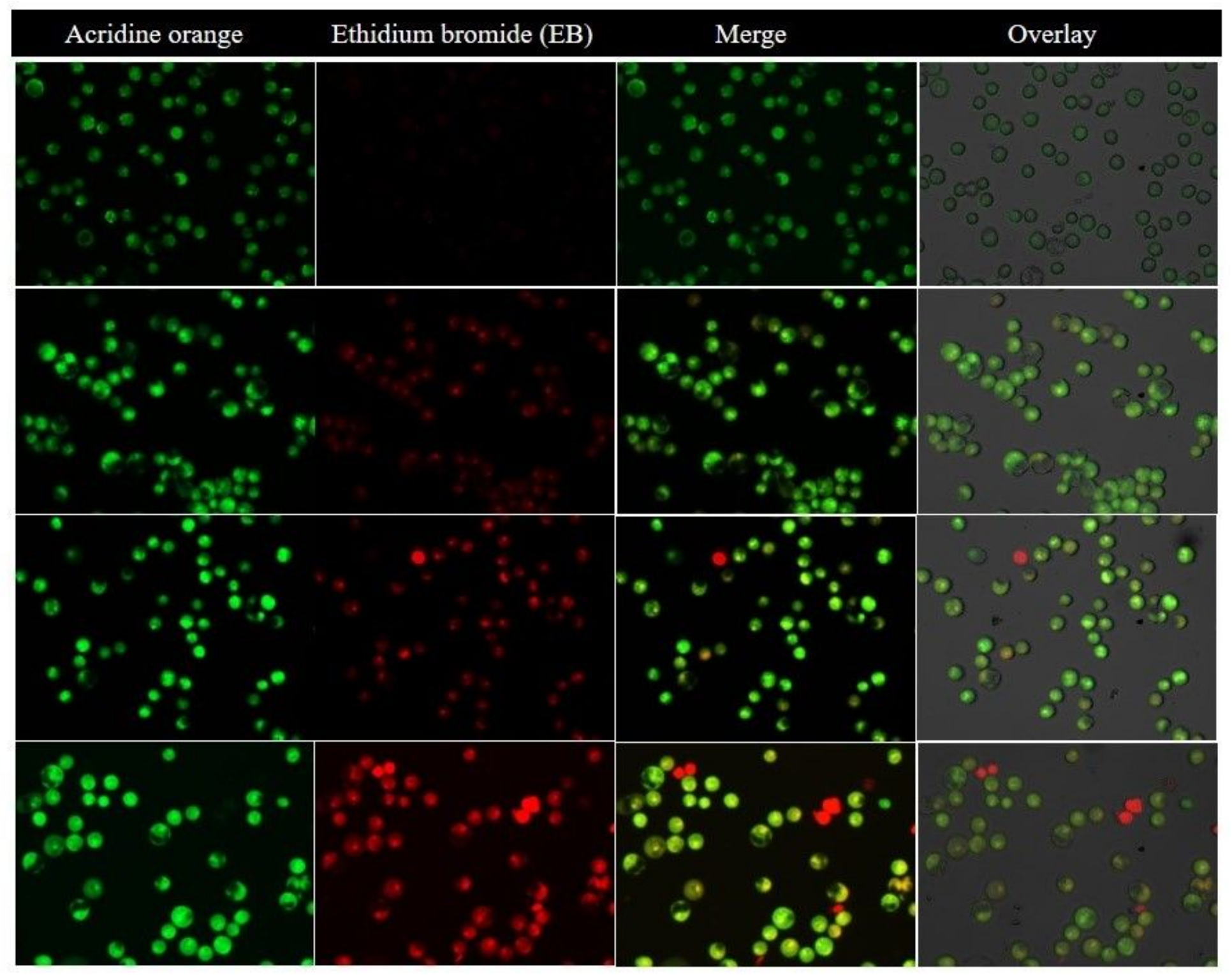

Figure 4

Composite images of DL cells stained with $\mathrm{AO} / \mathrm{EtBr}$ after 24hrs treatment with various concentrations of MOML. 

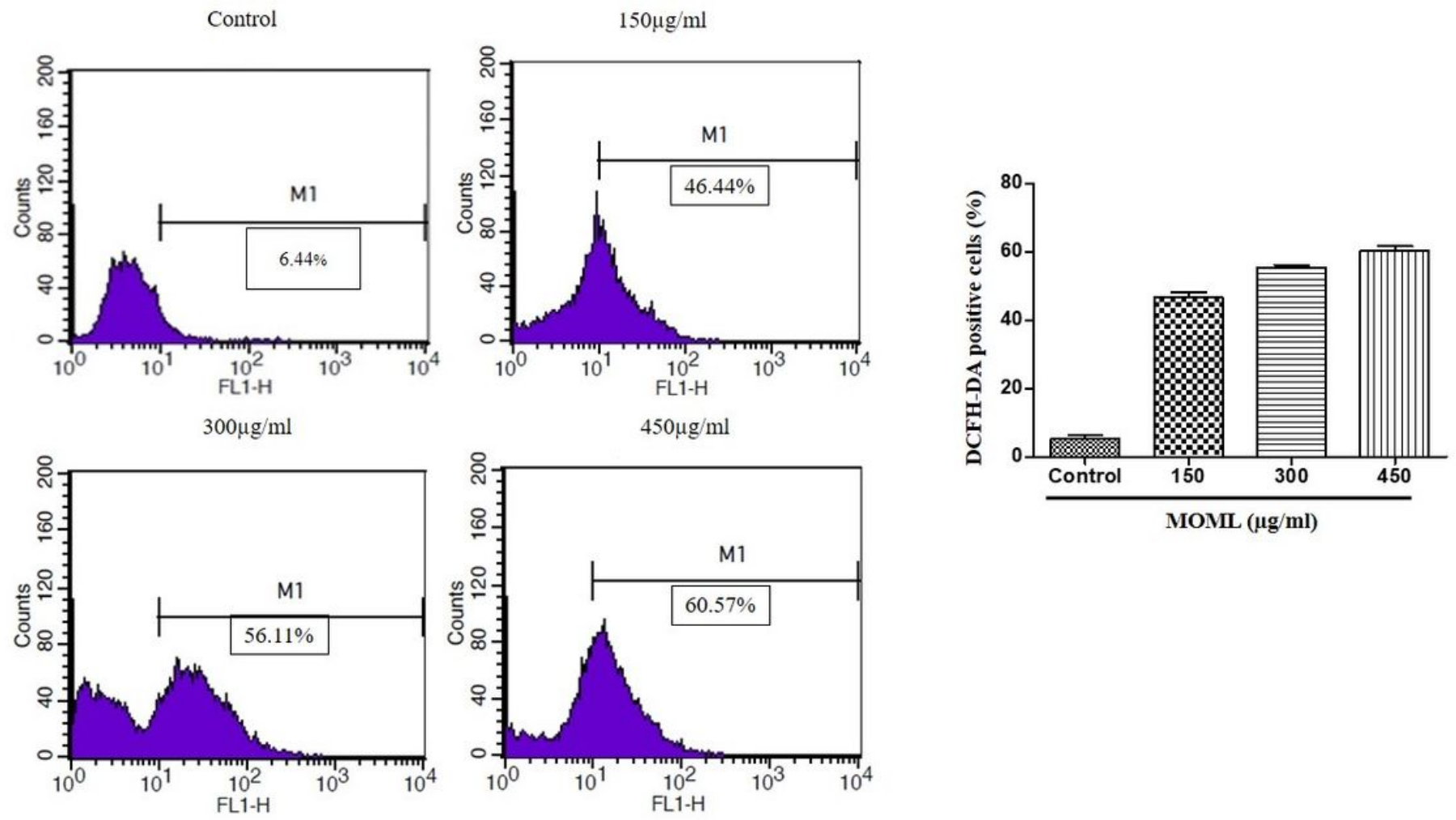

\section{Figure 5}

MOMLtreated and control cells analyzed by BD FACSCalibur flow cytometer. Bar graph showing increase in fluorescent intensity of H2DCFDA dose-dependent manner in MOML treated DL cells.

Control

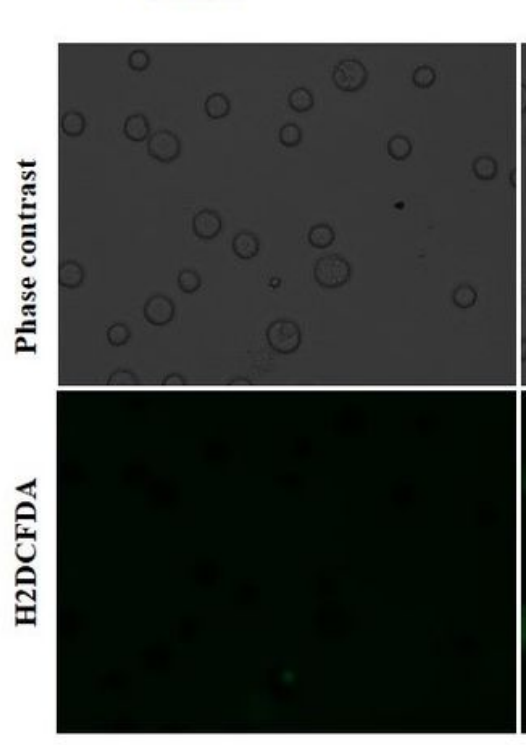

$150 \mu \mathrm{g} / \mathrm{ml}$

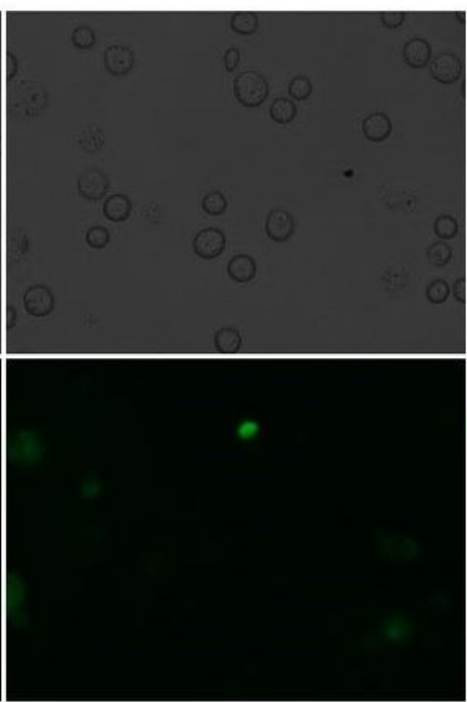

$300 \mu \mathrm{g} / \mathrm{ml}$

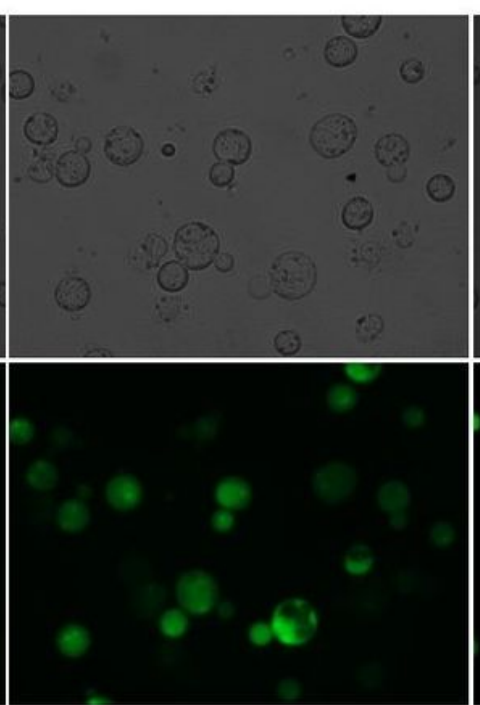

$450 \mu \mathrm{g} / \mathrm{ml}$

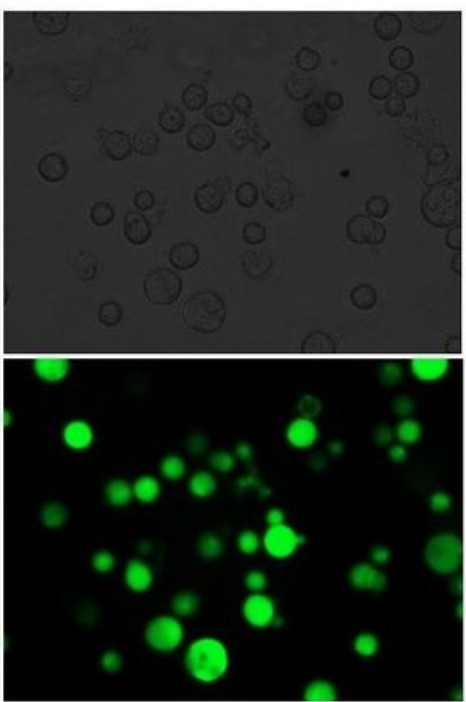

\section{Figure 6}

An increase in H2DCFDA fluorescence intensity was also visualized under a fluorescence microscope (EVOS) showing that ROS production has enhanced. 

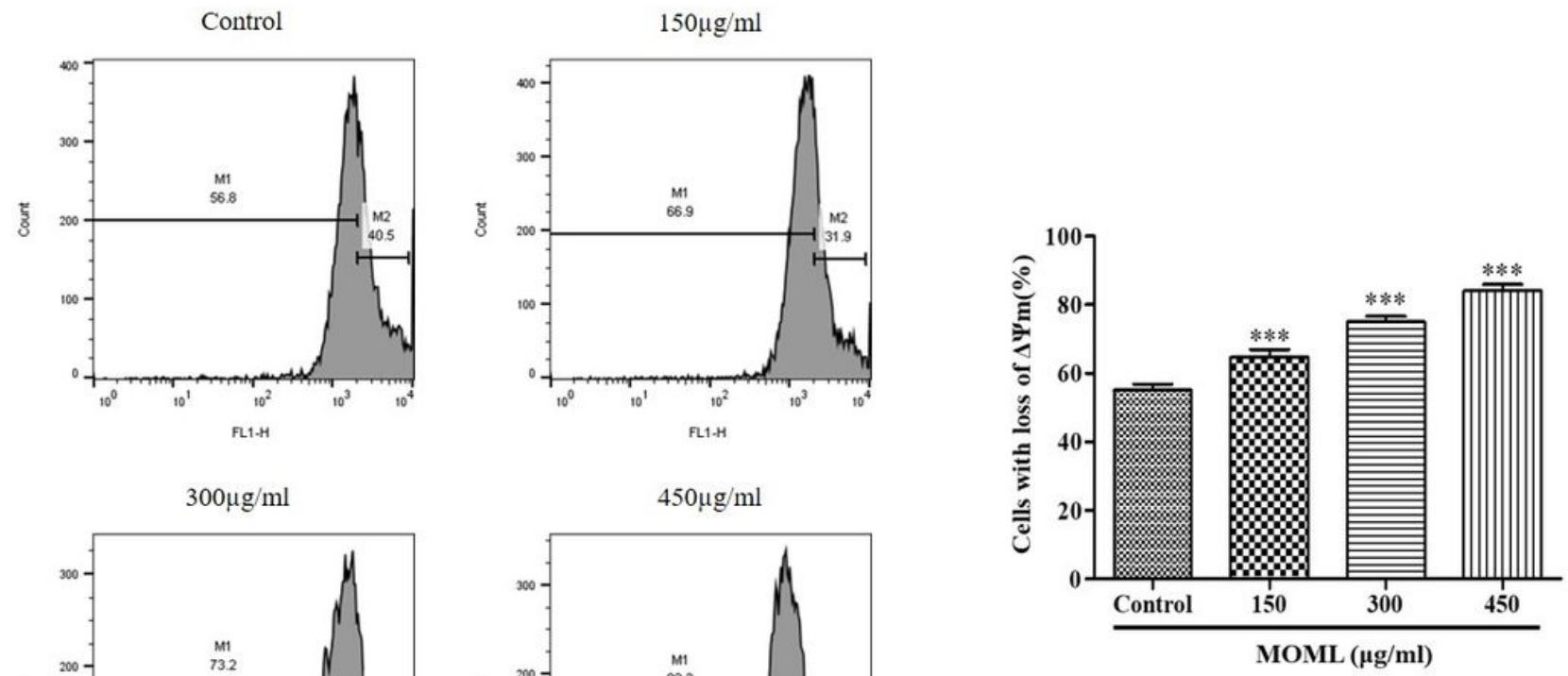

\section{Figure 7}

MOML treated and untreated cells were analyzed by BD FACS Calibur flow cytometer and results were analyzed by FlowJo software. Bar graph showing the dose-dependently decrease in fluorescent intensity of $\mathrm{Rh}-123$ in comparison with the untreated group. 


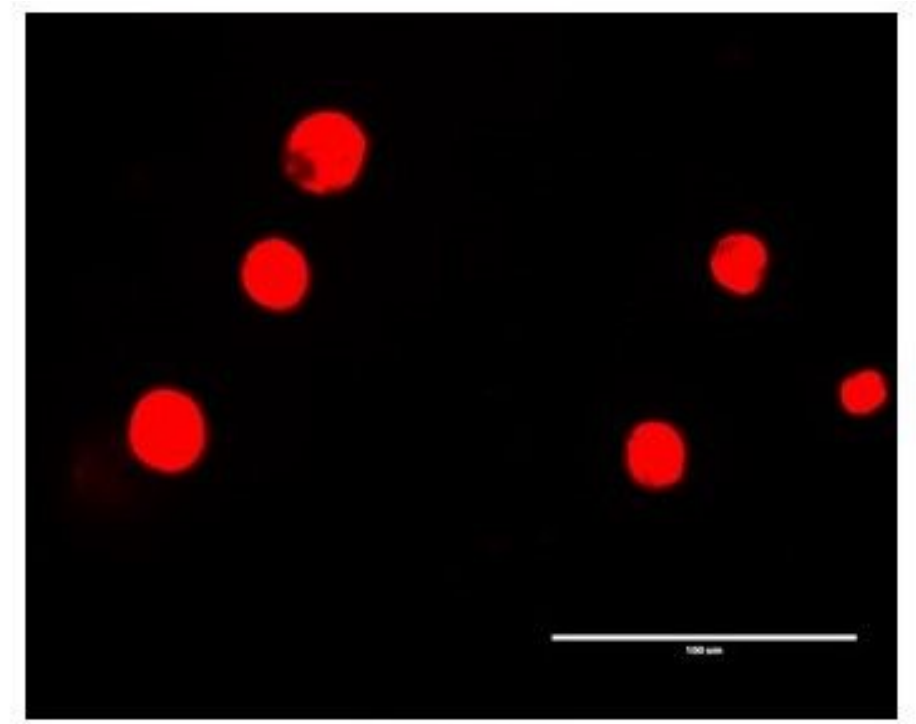

\section{Control}

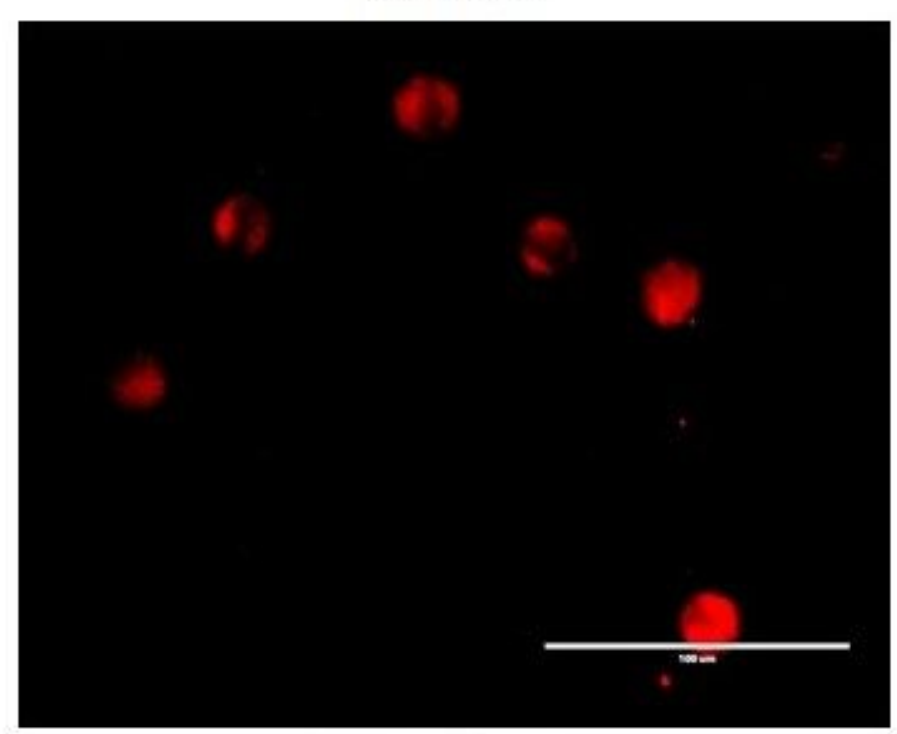

$300 \mu \mathrm{g} / \mathrm{ml}$

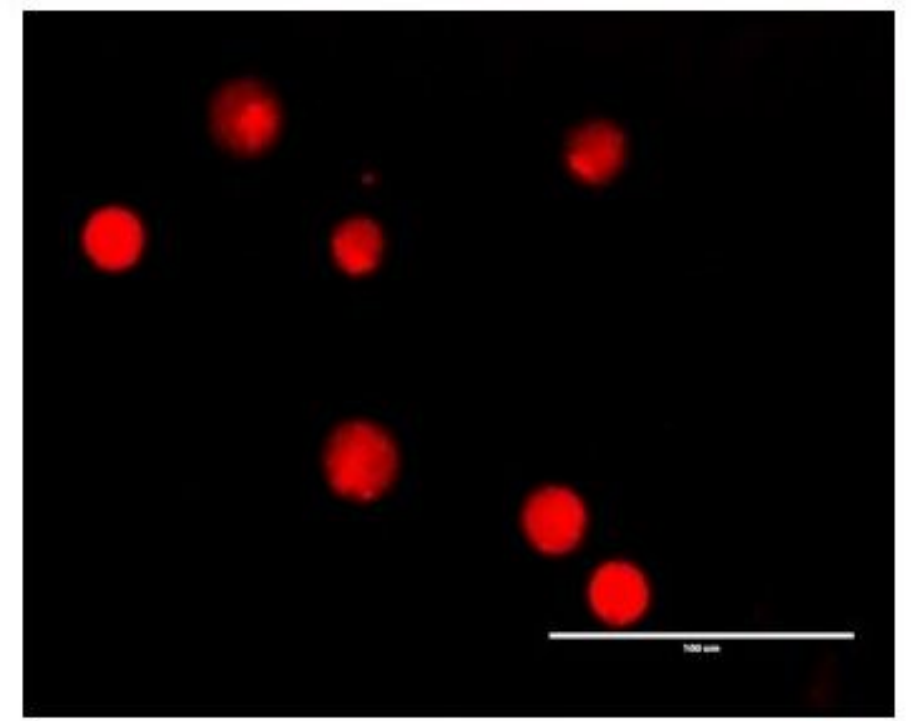

$150 \mu \mathrm{g} / \mathrm{ml}$

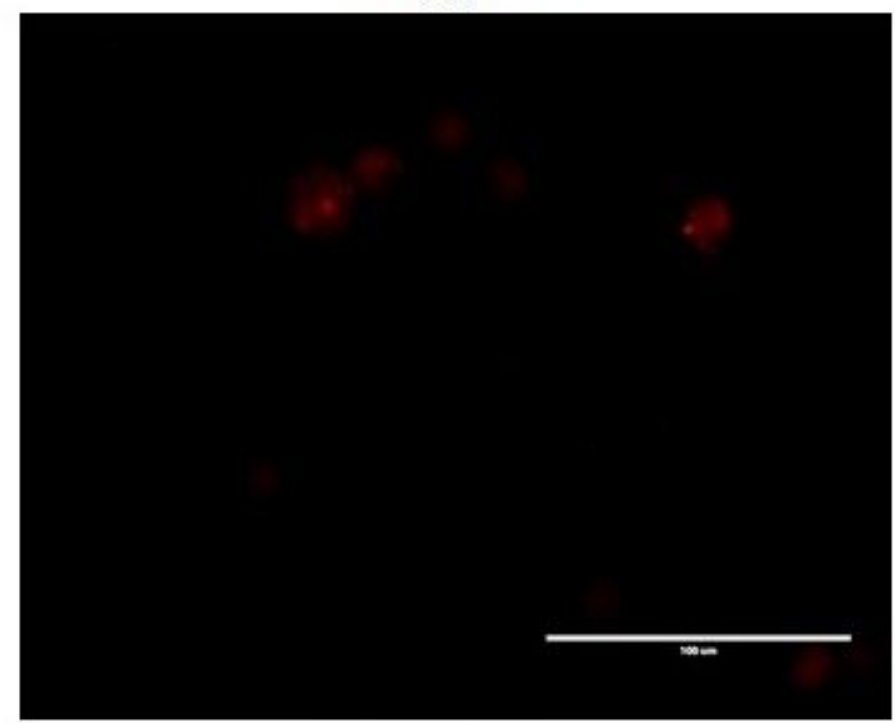

$450 \mu \mathrm{g} / \mathrm{ml}$

\section{Figure 8}

Decrease of the Rh-123 fluorescence intensity was also visualized under the fluorescence microscope (EVOS) representing that MMP has disrupted. 

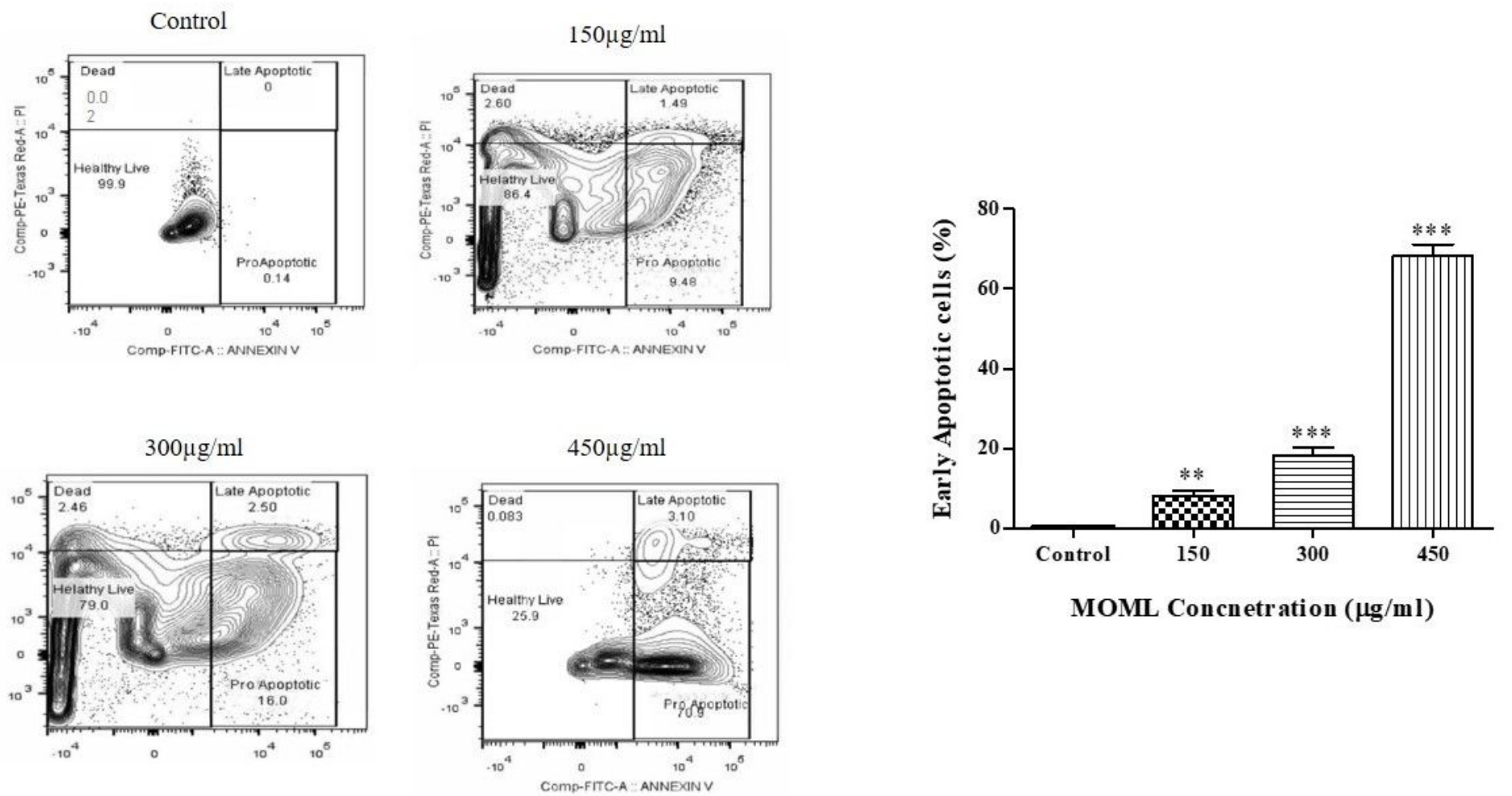

Figure 9

MOML induces apoptosis in Dalton's lymphoma cells. The DLcells, after being treated with different concentrations of MOML, were analyzed by flow cytometry. Annexin V/PI staining differentiated live, early-late apoptotic, and necrotic cells. Histogram represented the percentage of early apoptotic DL cells against various concentrations of MOML.
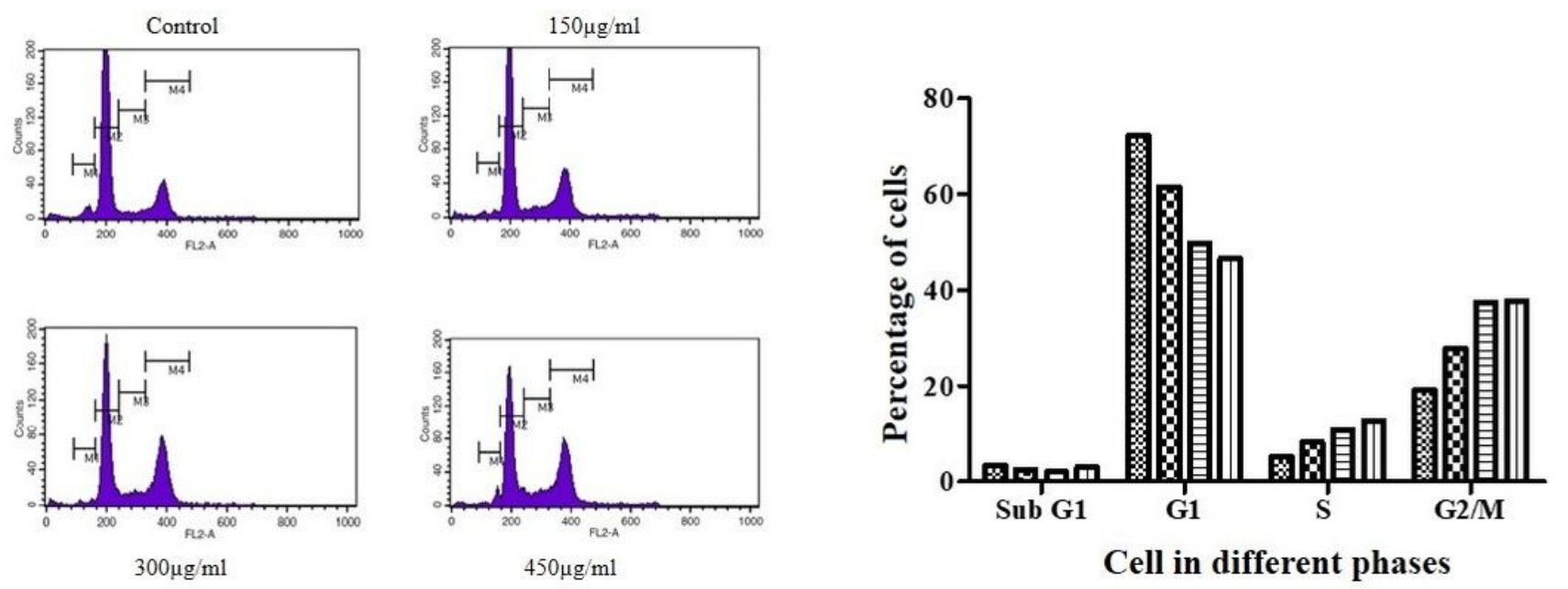

$\$$ control

150

ㄹ 300

띠 450

Cell in different phases

Figure 10

The Cell cycle analysis of DL cells stained with PI dye after $24 \mathrm{hrs}$ of treatment with various concentrations of MOML. 


$$
\text { Marker Control } \quad 300 \mu \mathrm{g} / \mathrm{ml} \quad 450 \mu \mathrm{g} / \mathrm{ml}
$$

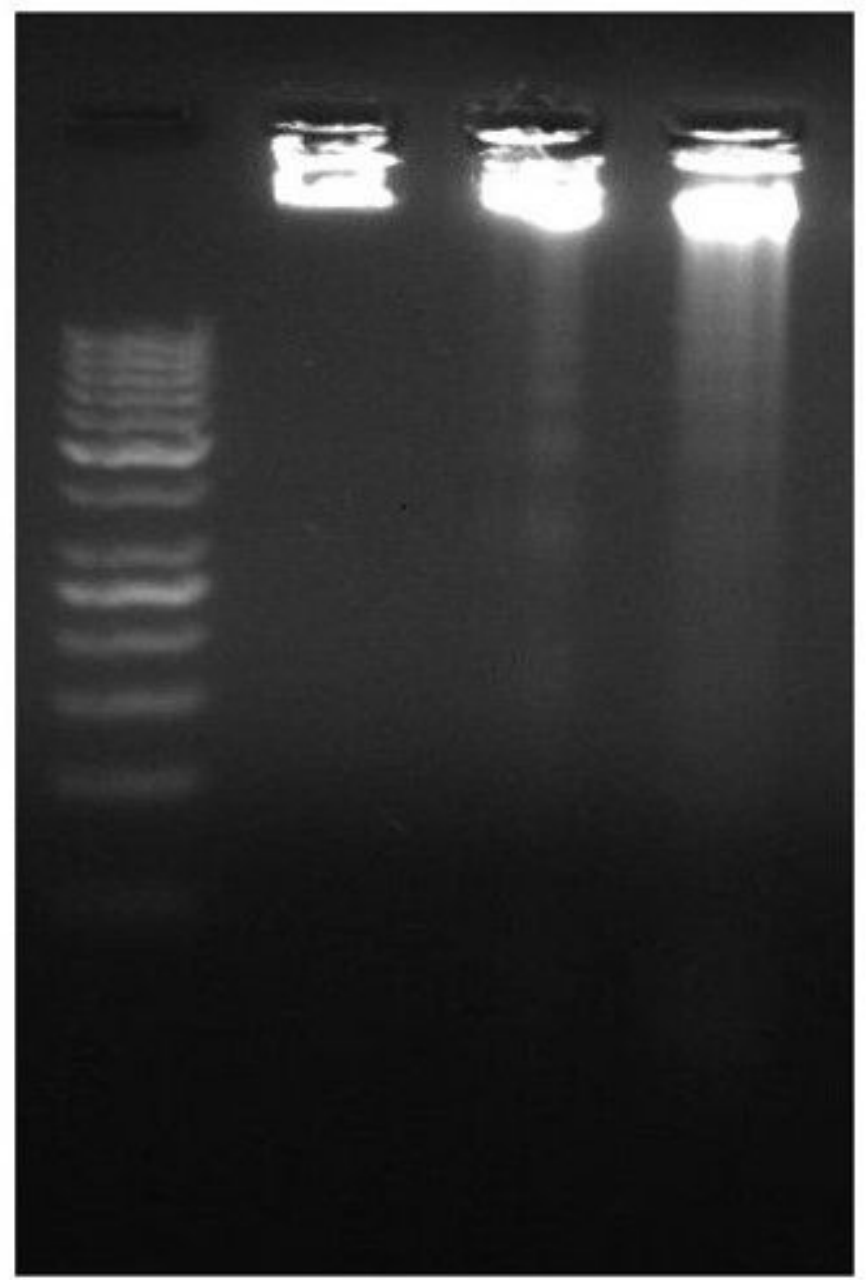

\section{Figure 11}

$1.8 \%$ Agarose gel electrophoresis was run to separate DNA fragments after incubation with various concentrations of MOML for 24hrs.

\section{Supplementary Files}

This is a list of supplementary files associated with this preprint. Click to download.

- Slide1.jpg 